\title{
Electrolyte Chemistry in 3D Metal Oxide Nanorod Arrays Deciphers Lithium Dendrite-Free Plating/Stripping Behaviors for High-Performance Lithium Batteries
}

Qian Li, ${ }^{\dagger \# \|}$ Zhen Cao, ${ }^{\dagger \$}$ Gang Liu, ${ }^{\# \|}$ Haoran Cheng, ${ }^{\# \|}$ Yingqiang Wu, ${ }^{\# \|}$ Hai Ming, ${ }^{* t}$ Geon-Tae

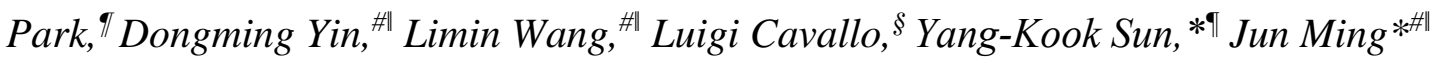

\# State Key Laboratory of Rare Earth Resource Utilization, Changchun Institute of Applied Chemistry, CAS, Changchun, 130022, China

" School of Applied Chemistry and Engineering, University of Science and Technology of China, Hefei, 230026, China

$\S$ Physical Science and Engineering Division, King Abdullah University of Science and Technology (KAUST), Thuwal, 23955-6900, Saudi Arabia

$\$$ Research Institute of Chemical Defense, Beijing, 100191, China

Il Department of Energy Engineering, Hanyang University, Seoul, 133-791, Republic of Korea

${ }^{\dagger}$ These authors contribute equally

*To whom correspondence should be addressed: hai.mingenergy@hotmail.com; yksun@ hanyang.ac.kr; jun.ming@ciac.ac.cn. 


\section{Experimental Section}

Materials. The commercial $\mathrm{Cu}$ foil was cleaned by 1.0 M hydrochloric acid ( $\mathrm{HCl})$, deionized water $\left(\mathrm{H}_{2} \mathrm{O}\right)$, and then ethanol consecutively to remove the surface impurities. Then, the rinsed

$\mathrm{Cu}$ foil was immersed in the aqueous solution containing $0.13 \mathrm{M}$ ammonium persulfate $\left(\left(\mathrm{NH}_{4}\right)_{2} \mathrm{~S}_{2} \mathrm{O}_{8}\right)$ and $2.6 \mathrm{M}$ sodium hydroxide $(\mathrm{NaOH})$ for 20 min until a faint blue $\mathrm{Cu}(\mathrm{OH})_{2}$ layer was formed on the surface of $\mathrm{Cu}$ foil. Later, the $3 \mathrm{D} \mathrm{Cu} / \mathrm{Cu}(\mathrm{OH})_{2}$ foil was taken out from the solution, washed with deionized water and ethanol several times, and then dried at room temperature. The as-prepared $3 \mathrm{D} \mathrm{Cu} / \mathrm{Cu}(\mathrm{OH})_{2}$ was thermally-treated at $400{ }^{\circ} \mathrm{C}$ for $2 \mathrm{~h}$ with a heating rate of $2{ }^{\circ} \mathrm{C} \min ^{-1}$ in a tube furnace under $\mathrm{Ar}$ or $\mathrm{Ar} / \mathrm{H}_{2}(95 / 5)$, giving rise to the 3D $\mathrm{Cu} / \mathrm{Cu}_{2} \mathrm{O}$ or $3 \mathrm{D} \mathrm{Cu} / \mathrm{Cu}$ nanorod arrays, respectively. Then, the $3 \mathrm{D} \mathrm{Cu} / \mathrm{Cu}_{2} \mathrm{O}$ (or $3 \mathrm{D} \mathrm{Cu} / \mathrm{Cu}$ ) electrode was punched out into a circular electrode with a diameter of $13.5 \mathrm{~mm}$ for assembling the battery used for lithium plating/stripping.

Materials Characterizations. The X-ray diffraction (XRD) patterns were carried out on a powder X-ray diffractometer (XRD, Bruker D8 Focus) to acquire the crystalline information. The morphology and microstructure of the lithium plated electrode were characterized by scanning electron microscopy (SEM, Hitachi S-4800) and transmission electron microscopy (TEM, FEI Tecani G2) with an EDX spectrometer using an accelerating voltage at $200 \mathrm{kV}$. The element and valence were performed by X-ray photoelectron spectra (XPS, ThermScientific ESCALAB 250) with $\mathrm{Al} \mathrm{K}_{\alpha}$ radiation. The electrode (i.e., 3D Cu/Cu $2 \mathrm{O}$ ) after the activation and Li plating/stripping process was disassembled from the coin cell and washed carefully by the same solvent used in the electrolyte to remove the residual electrolyte, then dried at room temperature in an Ar-filled glovebox. The electrode was pasted directly onto the 
sample stage and sealed by the Mylar membrane for XRD characterizations. Also, the 3D $\mathrm{Cu} / \mathrm{Cu}-\mathrm{Li}_{2} \mathrm{O}-\mathrm{Li}$ (or 3D $\mathrm{Cu} / \mathrm{Cu}-\mathrm{Li}, \mathrm{Cu}-\mathrm{Li}$ ) electrodes were sealed in a self-designed device (i.e., avoid the oxygen and moisture contamination) and then transferred to the vacuum chamber for ex-situ SEM and XPS analyses.

Electrochemical Measurements. The 2032-type coin cell was used to evaluate the electrochemical performance, which was assembled in the an Ar-filled glove box $\left(\mathrm{O}_{2}, \mathrm{H}_{2} \mathrm{O}<\right.$ $0.5 \mathrm{ppm}$ ) using the electrolyte of 1.0 M lithium bis(trifluoromethylsulphonyl)imide (LiTFSI), 0.1 M lithium nitrate $\left(\mathrm{LiNO}_{3}\right)$ in dimethyl ether (DME) and 1,3-dioxolane (DOL) (v/v, 1:1). The half-cell (i.e., asymmetric cell) with the configuration of $3 \mathrm{D} \mathrm{Cu} / \mathrm{Cu}_{2} \mathrm{O}(3 \mathrm{D} \mathrm{Cu} / \mathrm{Cu}$, or $\mathrm{Cu}$ foil) electrode |Celgard 2400 separator | lithium metal was assembled to investigate the lithium plating/stripping behaviors under different current densities. The cell was operated first between $0.01 \mathrm{~V}$ and $1.0 \mathrm{~V}$ at $50 \mu \mathrm{A}$ for five cycles to remove the surface contaminations and form a stable SEI layer. The lithium was continually plated onto $3 \mathrm{D} \mathrm{Cu} / \mathrm{Cu}_{2} \mathrm{O}(3 \mathrm{D} \mathrm{Cu} / \mathrm{Cu}$ and $\mathrm{Cu}$ foil) electrode from $\mathrm{Li}$ metal at $0.25,0.5$, and $1.0 \mathrm{~mA} \mathrm{~cm}^{-2}$ until the cell expiry to test the short-circuit time $\left(\mathrm{T}_{\mathrm{sc}}\right)$. The cycle performance was tested by the symmetric cell, which was assembled by two pieces of identical lithium plated electrode (i.e., 3D $\mathrm{Cu} / \mathrm{Cu}-\mathrm{Li} 2 \mathrm{O}-\mathrm{Li}, 3 \mathrm{D}$ $\mathrm{Cu} / \mathrm{Cu}-\mathrm{Li}$, or $\mathrm{Cu}-\mathrm{Li}$ ). The plated lithium was controlled at $4.0 \mathrm{mAh} \mathrm{cm}^{-2}$, and then the symmetric cell was (dis-)charged at different current densities. Electrochemical impedance spectroscopy (EIS) and cyclic voltammograms (CV) measurements were carried out on a CHI660E electrochemical workstation.

The $\mathrm{LiFePO}_{4}$ and sulfurized polyacrylonitrile (SPAN) cathode ${ }^{[\mathrm{S} 1]}$ was prepared as below. The active material of $\mathrm{LiFePO}_{4}$ (or SPAN), acetylene black, and polyvinylidene fluoride 
(PVDF) with the mass ratio of 80:10:10 were mixed in N-methyl-2-pyrrolidone (NMP) to form a uniform slurry and then cast on the $\mathrm{Al}$ foil. The casted electrode was dried in a vacuum oven at $100{ }^{\circ} \mathrm{C}$ for $\mathrm{LiFePO}_{4}$ cathode $\left(60{ }^{\circ} \mathrm{C}\right.$ for SPAN cathode) for $12 \mathrm{~h}$ and punched into a circular electrode for battery assembly. The lithium-metal battery (or lithium-sulfur battery) has the configuration of 3D Cu/Cu-Li2 $\mathrm{O}-\mathrm{Li}$ (or Cu-Li) anode | Celgard 2400 separator $\mid \mathrm{LiFePO}_{4}$ (or SPAN) cathode, in which the electrolyte of 1.0 M LiTFSI, 0.1 $\mathrm{M} \mathrm{LiNO}_{3}$ in DME/DOL (v/v, 1:1) was used. The active materials loading of $\mathrm{LiFePO}_{4}$ and SPAN cathode were controlled at $3.5 \mathrm{mg} \mathrm{cm}^{-2}$ and $1.0 \mathrm{mg} \mathrm{cm}^{-2}$, respectively. The areal capacity of the plated lithium on the 3D $\mathrm{Cu} / \mathrm{Cu}-\mathrm{Li}_{2} \mathrm{O}-\mathrm{Li}$ electrode was fixed at $2.0 \mathrm{mAh} \mathrm{cm}^{-2}$. Then, the capacity ratio of $3 \mathrm{D} \mathrm{Cu} / \mathrm{Cu}-$ $\mathrm{Li}_{2} \mathrm{O}-\mathrm{Li}$ to LFP and SPAN is about 3.6:1 and 2.9:1, respectively, in which the used electrolyte amount is about $100 \mu \mathrm{L}$.

Computational Method. The density functional theory (DFT) calculations were performed using the revised Perdew-Burke-Ernzerhof ${ }^{[\mathrm{S} 2]}$ level of exchange functional. The electrons were described using the projector augmented wave (PAW) method ${ }^{[\mathrm{S3}]}$ with an energy cutoff of 450 $\mathrm{eV}$. The van der Waals interaction was described using the Grimme's dispersion correction. ${ }^{[\mathrm{S} 4]}$ We built the slab model for metal and metal oxides. Specifically, both $\mathrm{Cu}$ and $\mathrm{Li}_{2} \mathrm{O}$ have their (100) facet pointing toward the vacuum, and we used a 6-layer thickness slab to improve the calculation precision. To avoid the interaction between the model and its image, the $\mathrm{Cu}$ and the $\mathrm{Li}_{2} \mathrm{O}$ slab have a $12.78 \times 15.34 \AA$ and a $13.98 \times 13.98 \AA$ dimension, respectively. We kept the stoichiometry of the materials. The optimization was considered to be finished after the Hellman-Feynman force is smaller than $0.01 \mathrm{eV} / \AA$. 


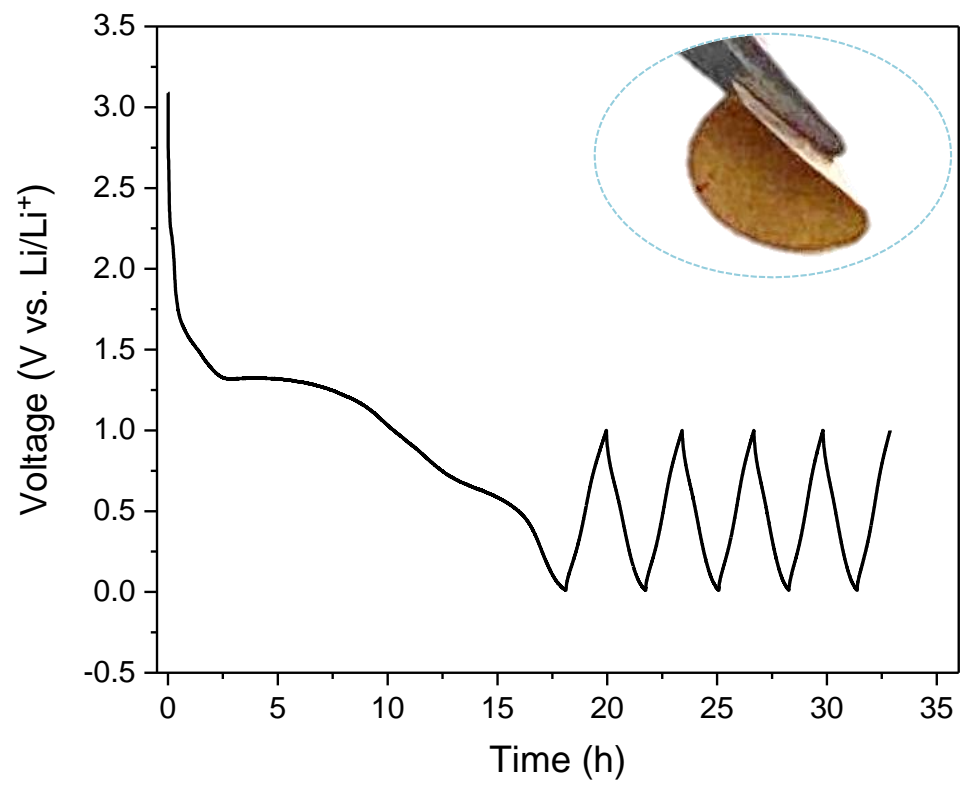

Figure S1. Formation of $\mathrm{Li}_{2} \mathrm{O}$. Typical voltage-time profile of the activation process. The batteries are first cycled between $0.01 \mathrm{~V}$ and $1.0 \mathrm{~V}\left(\mathrm{vs} . \mathrm{Li} / \mathrm{Li}^{+}\right)$at $50 \mu \mathrm{A}$ for five cycles before the measurements. The $\mathrm{Li}_{2} \mathrm{O}$ could be formed during the $1^{\text {st }}$ discharge process. Inset is the bending experiment for the as-prepared $3 \mathrm{D} \mathrm{Cu} / \mathrm{Cu}_{2} \mathrm{O}$ electrode. There is no obvious fracture and/or pulverization during the bending, demonstrating that the electrode has good mechanical stability. 

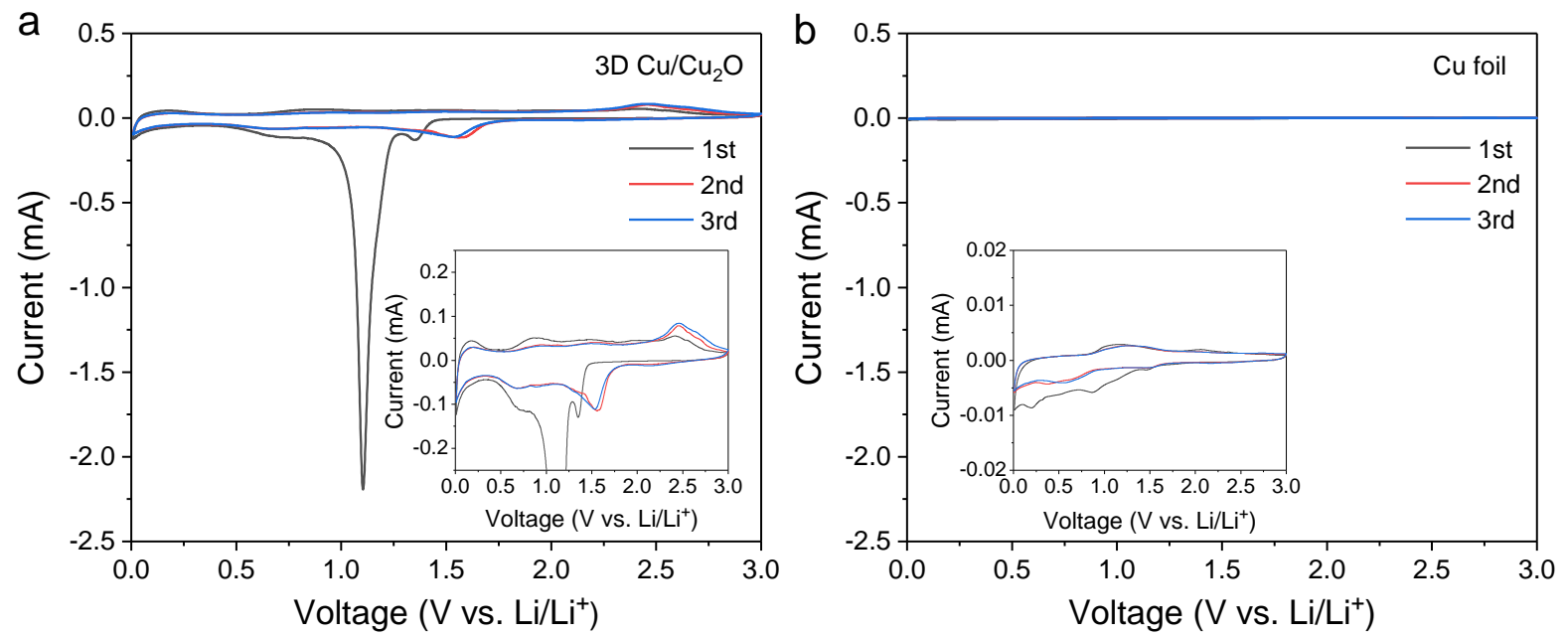

Figure S2. Evidence of forming $\mathrm{Li} 2 \mathrm{O}$. Comparative $\mathrm{CV}$ curves when the (a) $3 \mathrm{D} \mathrm{Cu} / \mathrm{Cu}_{2} \mathrm{O}$ and (b) $\mathrm{Cu}$ foil was used as electrode versus the lithium in the half-cell (i.e., asymmetric cell). The scan rate is $0.1 \mathrm{mV} \mathrm{s}^{-1}$. We find that obvious and continued peaks appeared around $1.36 \mathrm{~V}$ and 1.1 $\mathrm{V}$ in (a), demonstrating the formation of $\mathrm{Li}_{2} \mathrm{O}$ (i.e., $\mathrm{Cu}_{2} \mathrm{O}+2 \mathrm{Li}^{+}+2 \mathrm{e}^{-} \rightarrow 2 \mathrm{Cu}+\mathrm{Li}_{2} \mathrm{O}$ ) and electrolyte decomposition in the discharge process. The reversible peaks appeared around at $1.59 \mathrm{~V}$ and $2.47 \mathrm{~V}$ correspond to the formation/decomposition of $\mathrm{Li}_{2} \mathrm{O}$ during the (dis-)charge process. 


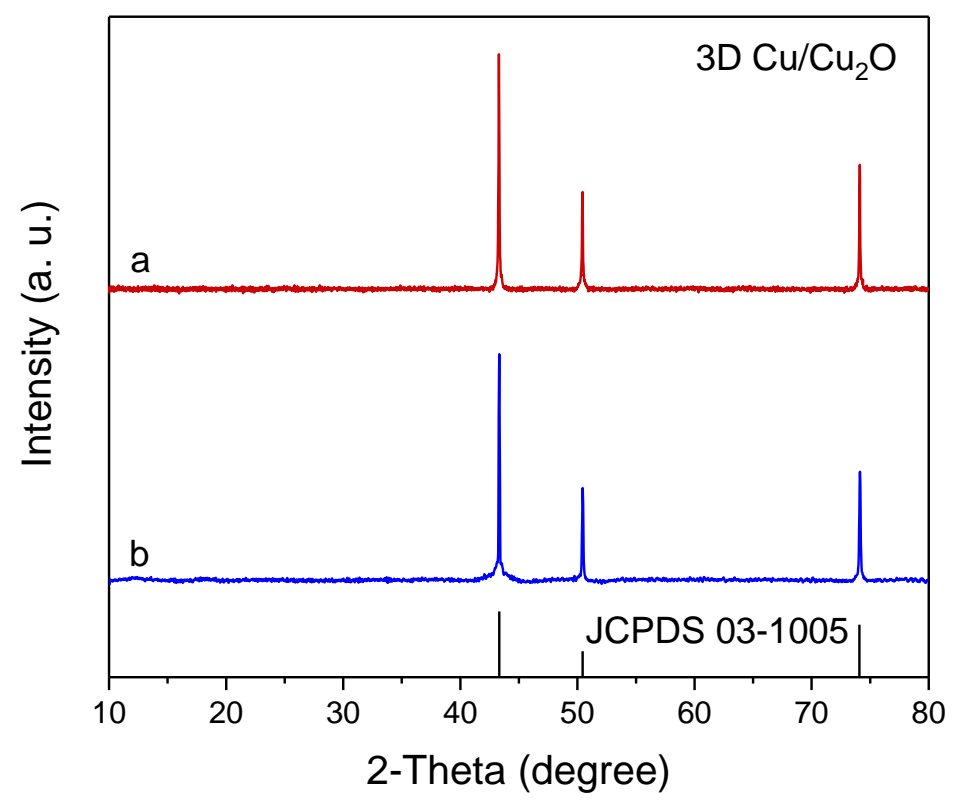

Figure S3. Crystalline characterizations of $\mathrm{Li}_{2} \mathrm{O}$. XRD patterns of $3 \mathrm{D} \mathrm{Cu} / \mathrm{Cu}_{2} \mathrm{O}$ electrode after (a) the $1^{\text {st }}$ discharge and (b) the $5^{\text {th }}$ charge at $50 \mu \mathrm{A}$. The cut-off voltage was controlled at 0.01-1.0 V (i.e., lower than the $\mathrm{Li}_{2} \mathrm{O}$ decomposition voltage) to make the $\mathrm{Li}_{2} \mathrm{O}$ maintained at the electrode surface well. There is no obvious variation in XRD patterns after the formation of $\mathrm{Li}_{2} \mathrm{O}$, demonstrating the amorphous feature of $\mathrm{Li}_{2} \mathrm{O}$. 

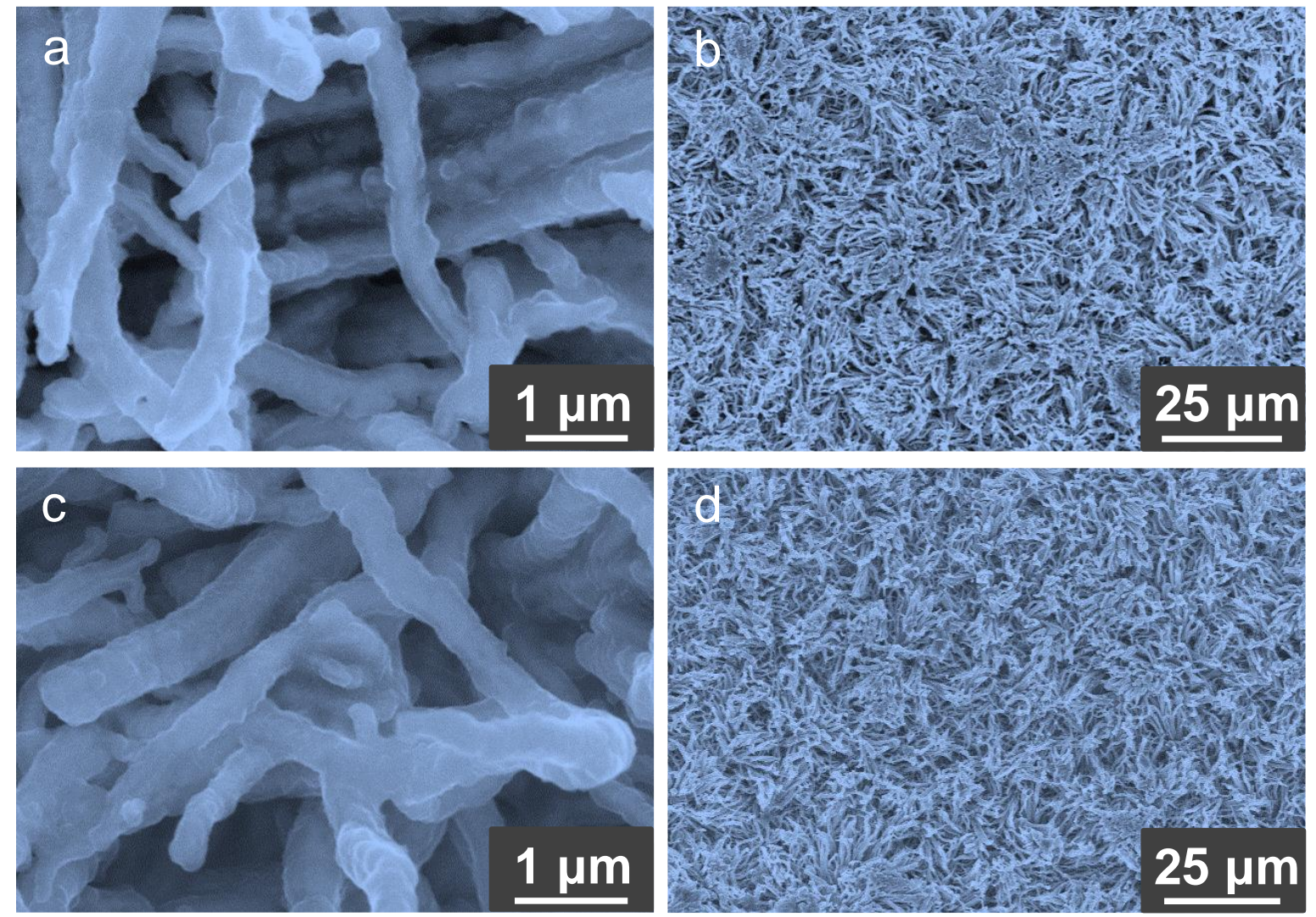

Figure S4. Morphology characterizations of $\mathrm{Li} \mathbf{i}_{2} \mathrm{O}$. SEM images of $3 \mathrm{D} \mathrm{Cu} / \mathrm{Cu}_{2} \mathrm{O}$ electrode after $(\mathrm{a}, \mathrm{b})$ the $1^{\text {st }}$ discharge and $(\mathrm{c}, \mathrm{d})$ the $5^{\text {th }}$ charge at $50 \mu \mathrm{A}$. The cut-off voltage was controlled at $0.01-1.0 \mathrm{~V}$ (i.e., lower than the $\mathrm{Li}_{2} \mathrm{O}$ decomposition voltage) to make the $\mathrm{Li}_{2} \mathrm{O}$ maintained at the electrode surface well. The SEM images demonstrate that the structure of $\mathrm{Li}_{2} \mathrm{O}$ could be maintained well on the electrode surface after the activation. 

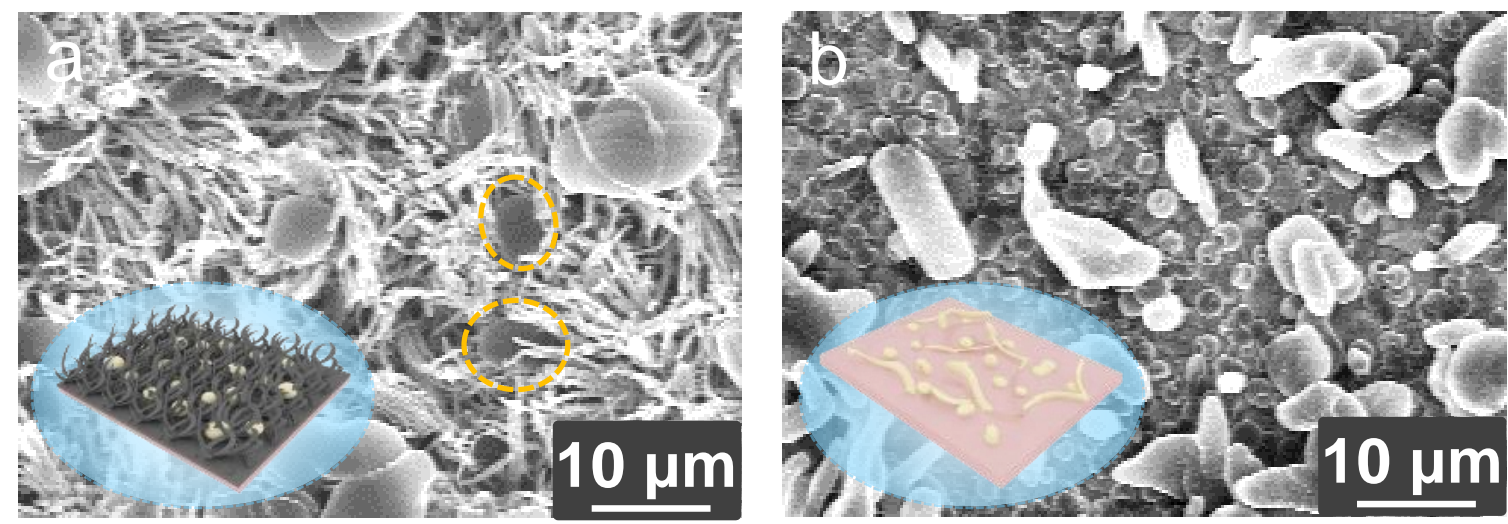

Figure S5. Lithium plating behaviors. SEM images of the plated $\mathrm{Li}$ on (a) $3 \mathrm{D} \mathrm{Cu} / \mathrm{Cu}_{2} \mathrm{O}$ electrode and (b) $\mathrm{Cu}$ foil with the areal capacity of $0.5 \mathrm{mAh} \mathrm{cm}^{-2}$. Insets are schematic illustrations of the plated $\mathrm{Li}$ on the electrode. We find that the spherical $\mathrm{Li}$ particles were deposited on the interspace of nanorod arrays. Then, the Li particle can behave as nucleation sites, which facilitates the $\mathrm{Li}$ deposition until the interspace of the $3 \mathrm{D} \mathrm{Cu} / \mathrm{Cu}_{2} \mathrm{O}$ was filled by the $\mathrm{Li}$ to form a dense $\mathrm{Li}$ layer. In contrast, the random $\mathrm{Li}$ is directly deposited on the surface of the $\mathrm{Cu}$ foil dispersedly, which eventually leads to the formation of lithium dendrite. 

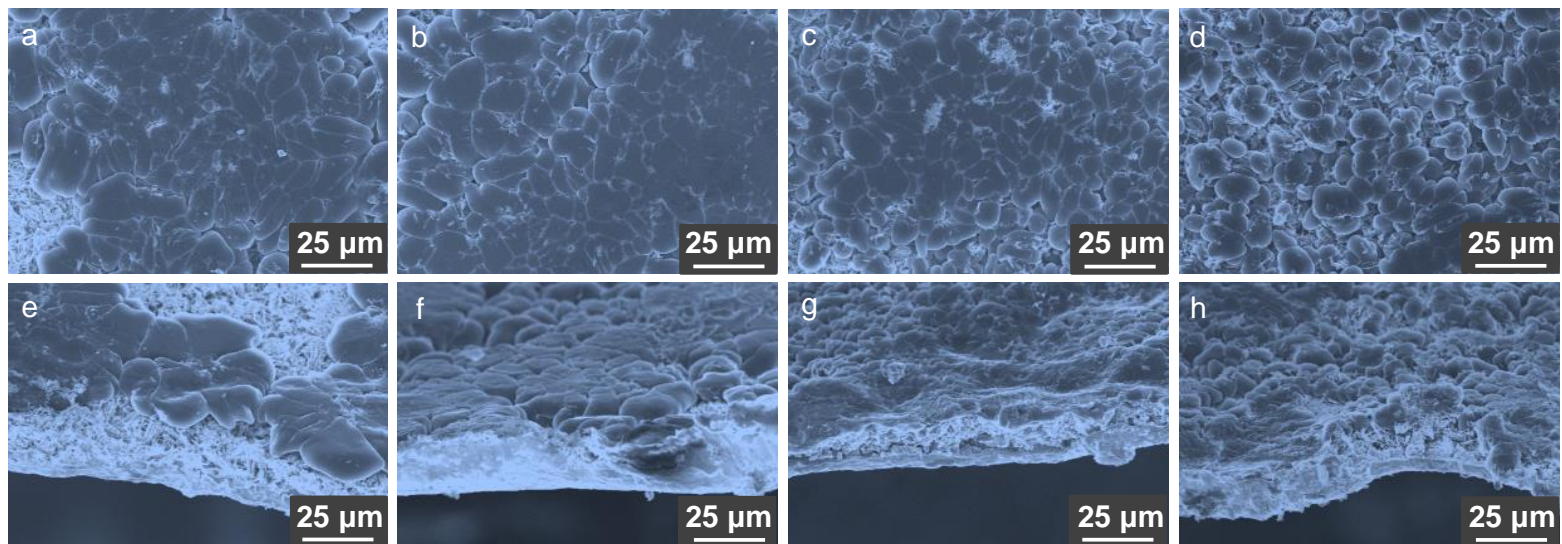

Figure S6. Li plating behaivors. Morphology of $2.0 \mathrm{mAh} \mathrm{cm}^{-2} \mathrm{Li}$ metal plated on the 3D $\mathrm{Cu} / \mathrm{Cu}_{2} \mathrm{O}$ electrode under different current densities of (a, e) $0.25 \mathrm{~mA} \mathrm{~cm}^{-2}$, (b, f) $0.5 \mathrm{~mA} \mathrm{~cm}^{-2}$, (c, g) $1.0 \mathrm{~mA} \mathrm{~cm}^{-2}$ and $(\mathrm{d}, \mathrm{h}) 2.0 \mathrm{~mA} \mathrm{~cm}^{-2}$. 


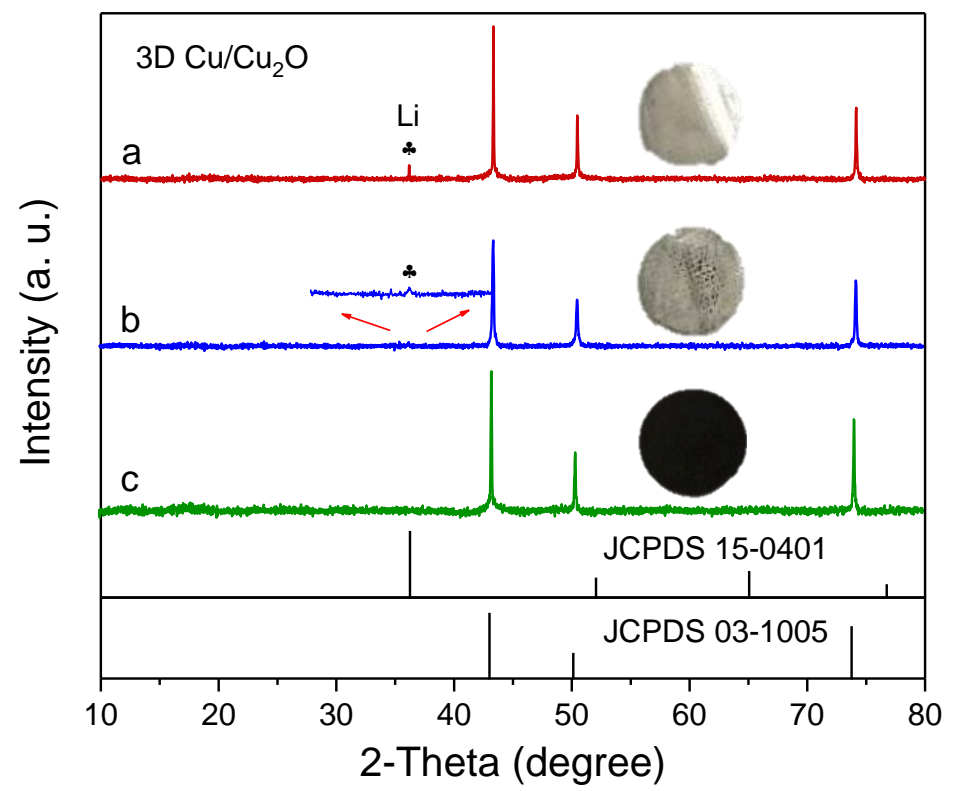

Figure S7. Crystalline characterizations of plated lithium. XRD patterns of the $3 \mathrm{D} \mathrm{Cu} / \mathrm{Cu}_{2} \mathrm{O}$ electrode after Li plating of (a) $4.0 \mathrm{mAh} \mathrm{cm}^{-2}$, and then stripping of (b) $2.0 \mathrm{mAh} \mathrm{cm}^{-2}$ and (c) $4.0 \mathrm{mAh} \mathrm{cm}{ }^{-2}$ (charged to $0.5 \mathrm{~V}$ ) at the current density of $0.5 \mathrm{~mA} \mathrm{~cm}$. The results show that the plated lithium has a crystalline structure, which could be stripped reversibly on the 3D $\mathrm{Cu} / \mathrm{Cu}_{2} \mathrm{O}$ electrode. 

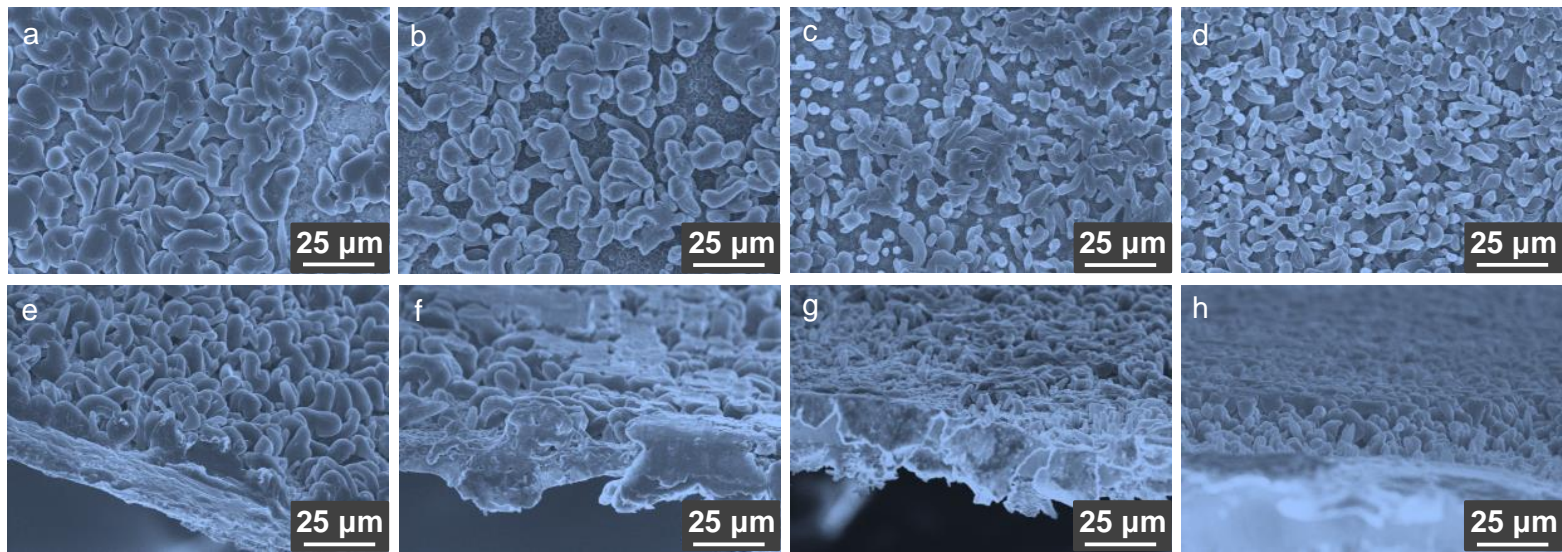

Figure S8. Morphology of plated $\mathrm{Li}$ on $\mathrm{Cu}$ foil. The $\mathrm{Li}$ was plated on the $\mathrm{Cu}$ foil with different capacities of $(\mathrm{a}, \mathrm{e}) 1.0 \mathrm{mAh} \mathrm{cm}^{-2},(\mathrm{~b}, \mathrm{f}) 2.0 \mathrm{mAh} \mathrm{cm}^{-2}$, (c, g) $3.0 \mathrm{mAh} \mathrm{cm}^{-2}$, and (d, h) $4.0 \mathrm{mAh} \mathrm{cm}{ }^{-2}$ at the current density of $0.5 \mathrm{~mA} \mathrm{~cm}^{-2}$. The results show that the lithium dendrite was always formed on the $\mathrm{Cu}$ foil regardless of capacities. 

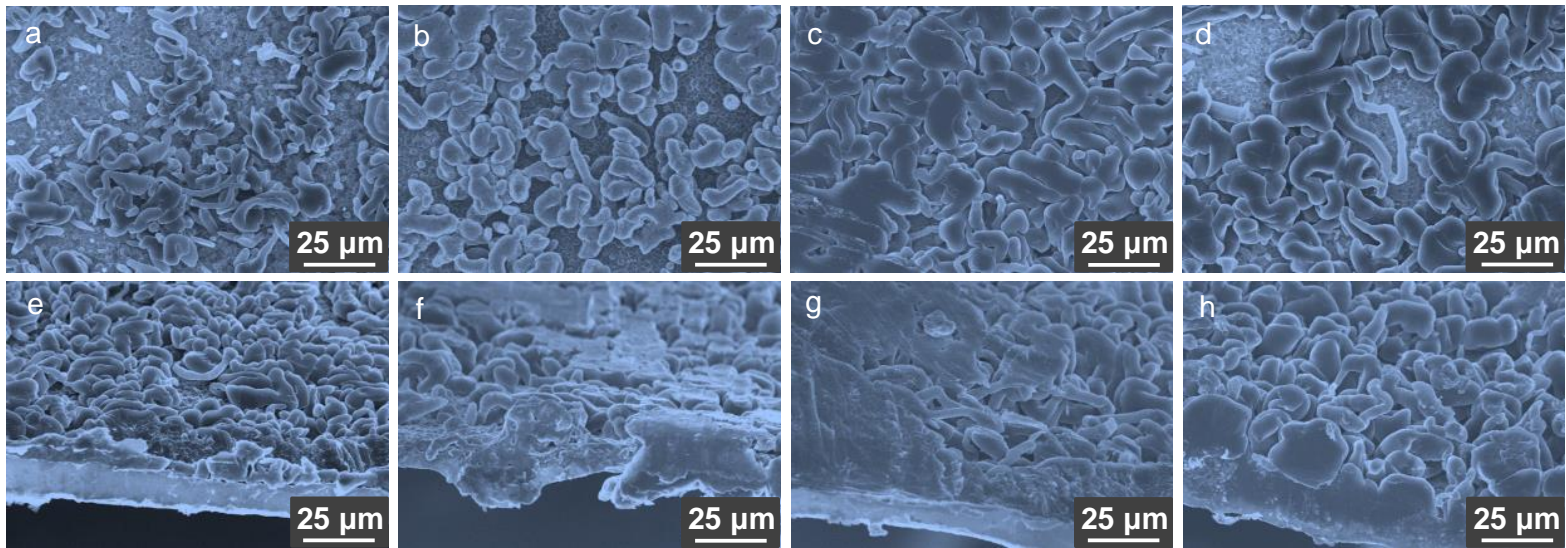

Figure S9. Morphology of plated $\mathrm{Li}$ on $\mathrm{Cu}$ foil. The $2.0 \mathrm{mAh} \mathrm{cm}^{-2} \mathrm{Li}$ was plated on the $\mathrm{Cu}$ foil under different current densities of (a, e) $0.25 \mathrm{~mA} \mathrm{~cm}^{-2},(\mathrm{~b}, \mathrm{f}) 0.5 \mathrm{~mA} \mathrm{~cm}{ }^{-2},(\mathrm{c}, \mathrm{g}) 1.0 \mathrm{~mA}$ $\mathrm{cm}^{-2}$ and $(\mathrm{d}, \mathrm{h}) 2.0 \mathrm{~mA} \mathrm{~cm}$. The results show that the lithium dendrite became more serious when the current densities were increased. 


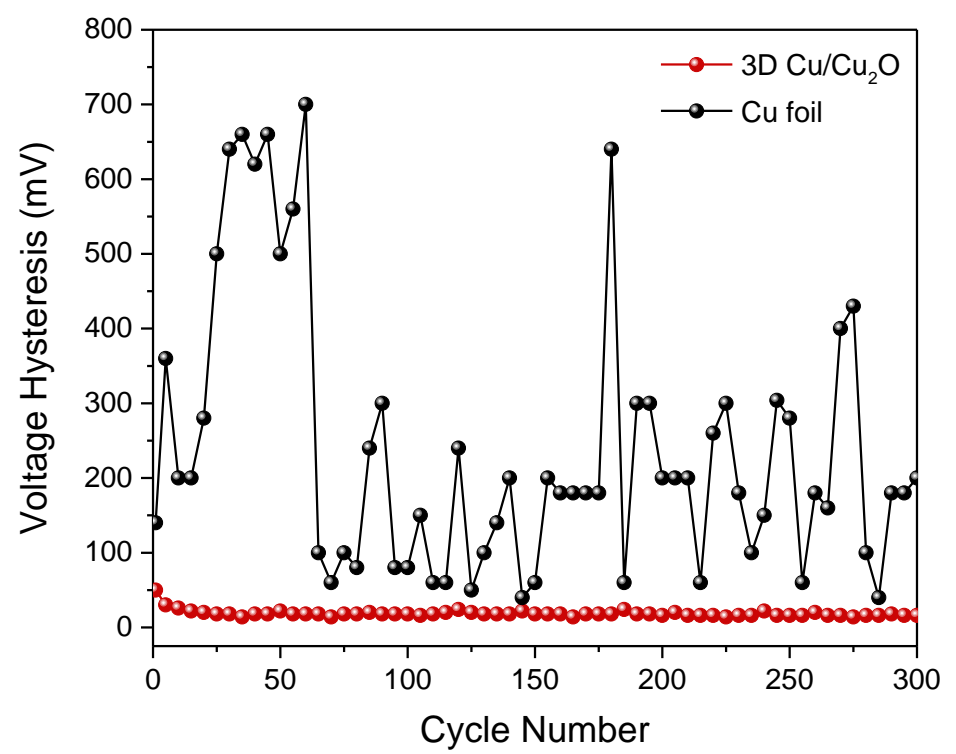

Figure S10. Comparison of voltage hysteresis. The voltage hysteresis of the $3 \mathrm{D} \mathrm{Cu} / \mathrm{Cu}_{2} \mathrm{O}$ electrode and $\mathrm{Cu}$ foil at the current density of $0.25 \mathrm{~mA} \mathrm{~cm}{ }^{-2}$ with a capacity of $0.5 \mathrm{mAh} \mathrm{cm}$. 


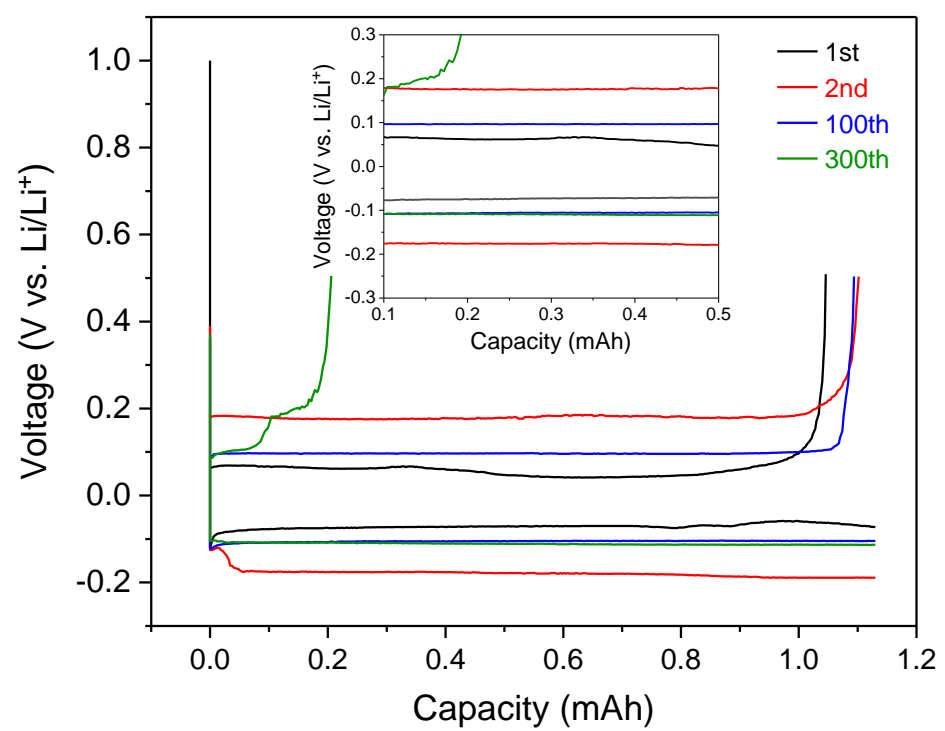

Figure S11. Voltage-capacity profiles on the $\mathrm{Cu}$ foil. Typical voltage-capacity profiles of the $\mathrm{Cu}$ foil at the $1^{\text {st }}, 2^{\text {nd }}, 100^{\text {th }}$, and $300^{\text {th }}$ cycles during the Li plating/stripping process at the current density of $0.25 \mathrm{~mA} \mathrm{~cm}{ }^{-2}$ with a capacity of $0.5 \mathrm{mAh} \mathrm{cm}$. 

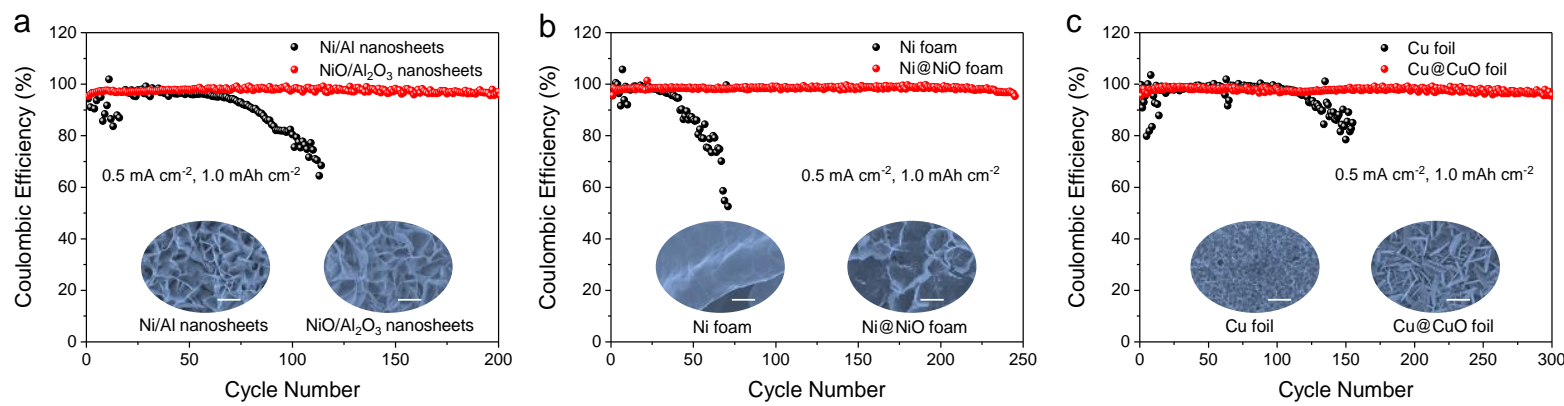

Figure S12. Extension of studying other metal (oxide) electrode behaviors. Comparison of the Coulombic efficiency of different metal oxide and metal nanoarrays used as the working electrode versus the lithium metal at the current density of $0.5 \mathrm{~mA} \mathrm{~cm}^{-2}$ with a capacity of 1.0 $\mathrm{mAh} \mathrm{cm}^{-2}$. (a) $\mathrm{NiO} / \mathrm{Al}_{2} \mathrm{O}_{3}$ nanosheets and $\mathrm{Ni} / \mathrm{Al}$ nanosheets, (b) $\mathrm{Ni} @ \mathrm{NiO}$ foam and $\mathrm{Ni}$ foam, and (c) $\mathrm{Cu} @ \mathrm{CuO}$ foil and $\mathrm{Cu}$ foil. Insets are corresponding SEM images of metal oxide and metal nanoarrays. 


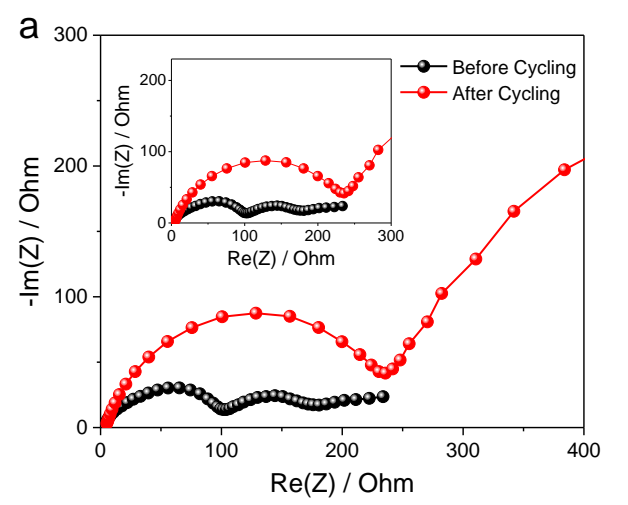

b

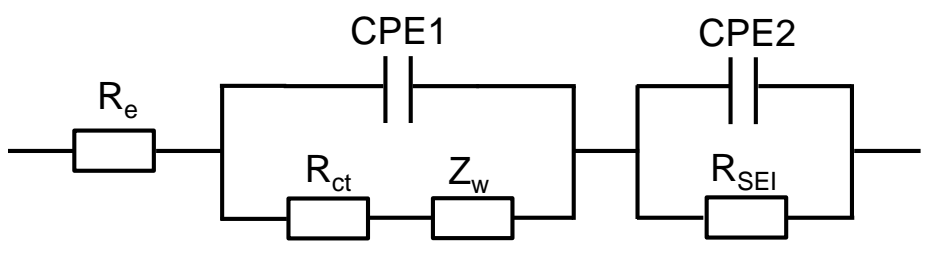

Figure S13. Impedance analysis of $\mathrm{Cu}$ foil. (a) EIS curves of $\mathrm{Cu}$ foil before and after 300 cycles in symmetric cells at the current density of $0.25 \mathrm{~mA} \mathrm{~cm}{ }^{-2}$ with a capacity of $0.5 \mathrm{mAh}$ $\mathrm{cm}^{-2}$. (b) Equivalent circuit diagram for EIS plots in Figure 4e and Figure S12a. 


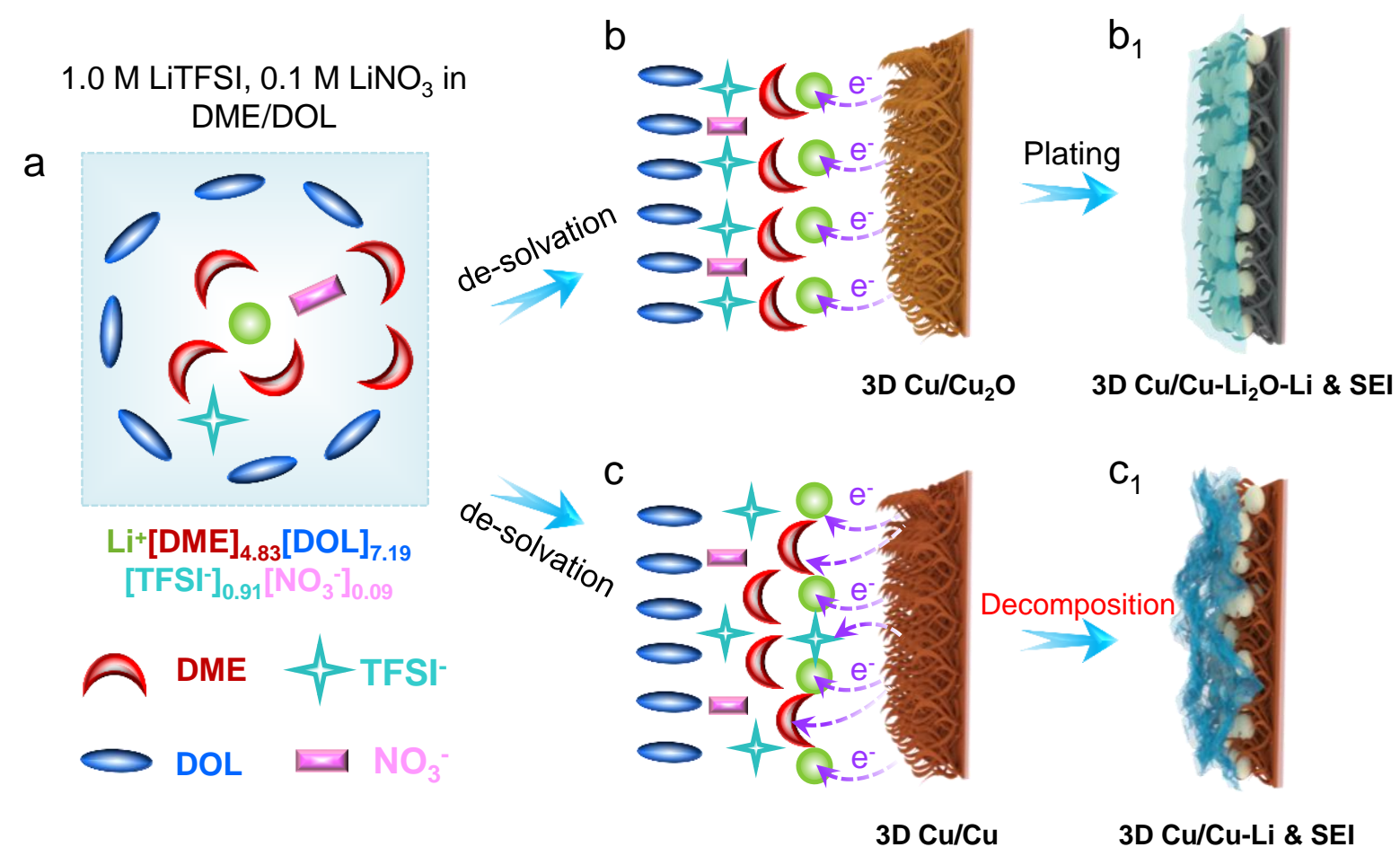

Figure S14. Interfacial model of the competitive reaction pathways for $\mathrm{Li}^{+}$solvation structure. (a) Schematical illustration of $\mathrm{Li}^{+}$solvation structure. The $\mathrm{Li}^{+}$-solvent-anion appearance around the (b) $3 \mathrm{D} \mathrm{Cu} / \mathrm{Cu}_{2} \mathrm{O}$ electrode, (c) $3 \mathrm{D} \mathrm{Cu} / \mathrm{Cu}$ electrode surface after the $\mathrm{Li}^{+}$ desolvation during the discharge process. $\left(b_{1}\right)$ Dendrites-free lithium deposition and thin SEI (i.e., mitigated electrolyte decomposition) formed on the $3 \mathrm{D} \mathrm{Cu} / \mathrm{Cu}_{2} \mathrm{O}$ electrode. $\left(\mathrm{c}_{1}\right)$ Dendrites free lithium deposition and thick SEI (i.e., serious electrolyte decomposition) observed on the 3D Cu/Cu electrode. The results show that the electrode properties can affect $\mathrm{Li}^{+}$-solvent-anion behaviors on the electrode surface (i.e., different interfacial models), which can lead to a different degree of electrolyte decomposition. 
Table S1. Comparison of the Li plating/stripping behaviors on the $3 \mathrm{D} \mathrm{Cu} / \mathrm{Cu}_{2} \mathrm{O}$ electrode and other electrodes reported before in Li metal batteries.

\begin{tabular}{lccc}
\hline Kind of electrode & $\begin{array}{c}\text { Current density } \\
\left(\mathrm{mA} \mathrm{cm}^{-2}\right)\end{array}$ & $\begin{array}{c}\text { Cycling } \\
\text { time }\end{array}$ & Ref. \\
\hline $\mathrm{Cu} / \mathrm{CuO}$ nanosheets & 0.5 & 700 & 14 \\
3D porous $\mathrm{Cu}$ foil & 0.2 & 600 & 43 \\
3D PI-clad copper current collectors & 0.2 & 500 & 44 \\
$\begin{array}{l}\text { Sulfur-dioxide-bubbled electrolyte } \\
\text { 3D nanoporous/macroporous structure }\end{array}$ & 0.5 & 200 & 45 \\
$\begin{array}{l}\text { Cu current collector } \\
\text { Sandwich-structured nano/micro fiber- } \\
\text { based separators }\end{array}$ & 0.5 & 400 & 46 \\
$\begin{array}{l}\text { Polymer-in-salt polysiloxane } \\
\text { electrolyte }\end{array}$ & 0.65 & 600 & 47 \\
3D porous Cu current collectors & 0.5 & 300 & 48 \\
SPE-LLZTO-SPE & 0.5 & 700 & 49 \\
Li-dual carbon composite & 0.5 & 700 & 50 \\
3D Cu/Cu2O electrode & 0.25 & 300 & 51 \\
\hline
\end{tabular}


Table S2. Fitted impedance results of the $3 \mathrm{D} \mathrm{Cu} / \mathrm{Cu}_{2} \mathrm{O}$ electrode, $3 \mathrm{D} \mathrm{Cu} / \mathrm{Cu}$ electrode, and $\mathrm{Cu}$ foil before and after 300 cycles.

\begin{tabular}{l|c|c|c}
\hline \multirow{2}{*}{ Kind of electrode } & & $\mathrm{R}_{\text {SEI }}(\Omega)$ & $\mathrm{R}_{\mathrm{ct}}(\Omega)$ \\
\hline \multirow{2}{*}{$3 \mathrm{D} \mathrm{Cu} / \mathrm{Cu}_{2} \mathrm{O}$ electrode } & Before cycling & 38 & 14 \\
\cline { 2 - 4 } & After cycling & 15 & 15 \\
\hline \multirow{2}{*}{$3 \mathrm{D} \mathrm{Cu} / \mathrm{Cu}$ electrode } & Before cycling & 115 & 65 \\
\cline { 2 - 4 } & After cycling & 167 & 84 \\
\hline \multirow{2}{*}{$\mathrm{Cu}$ foil } & Before cycling & 102 & 75 \\
\cline { 2 - 4 } & After cycling & 241 & 103 \\
\hline
\end{tabular}


Table S3. Comparison of the SPAN cathode performance in the 3D $\mathrm{Cu} / \mathrm{Cu}-\mathrm{Li}_{2} \mathrm{O}-\mathrm{Li}$ | SPAN cell with those using lithium metal anode reported before.

\begin{tabular}{lcccc}
\hline Kind of electrode & $\begin{array}{c}\text { Current density } \\
\left(\mathrm{mA} \mathrm{g}^{-1}\right)\end{array}$ & $\begin{array}{c}\text { Cycling } \\
\text { number }\end{array}$ & $\begin{array}{c}\text { Specific capacity } \\
\left(\mathrm{mAh} \mathrm{g}^{-1}\right)\end{array}$ & Ref. \\
\hline Li metal anode & 100 & 100 & 425 & 60 \\
Li metal anode & 100 & 40 & 475 & 61 \\
Li metal anode & $0.1 \mathrm{C}$ & 40 & 348 & 62 \\
Li metal anode & 110 & 80 & 700 & 63 \\
Li metal anode & 160 & 100 & 650 & 64 \\
Li metal anode & $0.1 \mathrm{C}$ & 50 & 675 & 65 \\
Li metal anode & 100 & 100 & 500 & 66 \\
Li metal anode & $0.5 \mathrm{C}$ & 100 & 746 & 67 \\
3D Cu/Cu-Li $2 \mathrm{O}-\mathrm{Li}$ & $0.1 \mathrm{C}$ & 100 & 448 & This \\
electrode & & & & work \\
\hline
\end{tabular}




\section{REFERENCE}

(1) Yu, L.; Zhou, H.; Sun, J.; Qin, F.; Yu, F.; Bao, J.; Yu, Y.; Chen, S.; Ren, Z., Cu Nanowires Shelled with NiFe Layered Double Hydroxide Nanosheets as Bifunctional Electrocatalysts for Overall Water Splitting. Energy Environ. Sci. 2017, 10, 1820-1827.

(2) Zhang, Y.; Yang, W., Comment on "Generalized Gradient Approximation Made Simple". Phys. Rev. Lett. 1998, 80, 890-890.

(3) Blochl, P. E., Projector Augmented-Wave Method. Phys. Rev. B Condens. Matter. 1994, 50, 17953-17979.

(4) Grimme, S.; Antony, J.; Ehrlich, S.; Krieg, H., A Consistent and Accurate ab Initio Parametrization of Density Functional Dispersion Correction (DFT-D) for the 94 Elements H-Pu. J. Chem. Phys. 2010, 132, 154104-154123. 